\title{
Intellectual Capital and the Organisational Learning in the Knowledge Society
}

\section{Summary}

Organisational learning theory appears to be practical when researchers can find links between two or more variables that can be justifield and implemented the term ,intellectual capital" have appreciated over time into something of mach greater value. The paper argues that work based learning has the potential to contribute to the intellectual capital not only of employer partners but also to the university.

\section{Introduction}

Organisational learning is concerned with improving the behaviour and capability of individuals so that the organisation can more effectively respond ti its environment. Essentially, organisational learning is a time - honoured process that involves changing individual and organisation behaviour. Firms that have developed a strong learning culture are good at creating, acquiring and transferring knowledge and at modifying behaviour to reflect new knowledge and insight. Learning firms excel at creating shared vision, and allowing people to surface and challenge existing mental models.

\section{Linking learning and competence}

Strategic management theory provides several partways to explore organisational learning and successful corporate stategy has been more often attributable to the resource capability of the organisation.

\footnotetext{
* Profesorowie, Academy of Economic Studies, Bucharest, Romania.
} 
The competencies of a firm are what it can do as a result of resources working together whereas capabilities involve complex patterns of coordonation between people, and between people and other resources that lead to sustainable competitive advantage over time. Strategic actions are the manifestation of the competence that the learning has created and made possible.

Studies have found that some managerial competencies can be positively correlated to current business performance while others with effective organisational change. Superior technical and management competencies contribute to competitive advantage; management competencies have been found to create effective change in a variety of ways: commitment formation (achieving widespread commitment of the workforce), motivating and enthusing (motivating staff), enaction (taking timely and effective action), integration (coordinating action) and communication skills.

In the age of the „knowledge driven economy” and the „corporate university" the creation and evaluation of knowledge is now recognised as too important and all pervasive to be left to higher education. The once elite knowledge workers of the university are now joined by management gurus, chief executives and stock market analysts seeking to leverage and evaluate the „intellectual capital” of organisations. The intellectual capital may be divide into:

- Human capital - concerned with knowledge and capabilities of individuals and groups of workers.

- Structural capital - the means by which the organisation captures, develops, codifies and shares knowledge so that it can be effectively applied.

- Client capital - systems and processes by which the organisation taps into the human and structural capital of client organisations (suppliers, partners, customers).

Human capital regards the value that is created by a person. The ideas going around in people's minds and the solutions they create. There is a close relationship between the amount of human capital generated and the amount of corporate investments in people. To get more human capital accumulation, companies need to expose people to knowledge and to specific experiences. To manage human capital, it must be measurable. If companies want to manage better their use of knowledge, they need to know who has it, what and how much they know and if they know to use it. But how can we measure the hearts and minds of human beings? And how do we do it if we deal with a virtual corporation? Quantifying some of the multiple facets of human capital, identifying other meaningful measures, and then assessing them within the context of the company's strategy are the first steps toward valuing human capital.

Since „change is considered to be the single constant of the universe”, managing human capital in a creative and innovative way is crucial mostly in a global knowledge based society.

Structural capital is the glue of an organization. Its value depends on how well it enables a company to package, moveand use human capital - the company's knowledge - in service to corporate goals. 
Structural capital is not to be confused with computer hardware or equipment, which are already on the books as assets. Rather, structural capital is a company's capability to use these tools to contribute to profitability:

- Management philophy - what company leaders believe about their company, their employees and their mission.

- Corporate culture - how a company does things-its styles and its values. The corporate culture should reflect management philosophy and be in line with corporate goals.

- Management processes - the mechanisms by which a company implements its philosophy. This includes how managers listen to employees, quality control processes, policies and procedures for managing knowledge, information and innovations.

- Information tehnology systems - the systems by which management processes are implemented. These systems are evaluated by how well they improve efficiency, customer care and employee satisfaction. They include customer databases, customer tracking and other means to make knowledge within a company of practical use.

- Networking systems - the ability for computers to network with others, thus providing access to customers, suppliers and databases. Evaluating networking systems reveals how well companies communicate both internally and externally.

- Financial relations - favorable relations with banks and investors that provide companies the flexibility they need to raise money quickly and to respond to environmental demands.

The combined value of these components depends on how well they work together to achieve the company's goals. The challenge in valuing structural capital is in measuring how well it serves a company's goals.

Client capital is other attribute that is source for a long-run competitive advantage based on managing effectively intellectual capital. The cognition aspects of product usability include the aspects of using the product, or how logical and natural a product is to use. The emotion aspects relates to how people feel about using it. Companies are using both. In particular, the notion of client capital is useful when considering the role of work based employer.

Increasing the amount of intellectual capital requires two critical enablers: managing its development and supplying the hardware and software information technology - the electron elixir essential to make more human, social and structural capital.

Work based learning offers the opportunity to fundamentally extend the intellectual capital of the university. Focusing on a university work based learning programme as a process for recognising, creating and applying knowledge through and for work rather than simply at work challenges the position of the university as sole validator and evaluator of high level knowledge. The need to demonstrate „fitness for purpose” typically not only requires traditional higher education cognitive abilities (analysis, synthesis, evaluation), but also demands 
that these be applied within complex situation to maximise resource effectiveness while taking into account stakeholder expectations and time constraints. By partnership with the university the employer is clearly drawing upon the client capital of the univesity in order to enhance its own human and structural capital. It is the contribution of the project to the structural capital of the employer partner as much as the development of transitory human capital which is emerging as the distinctive „added value” of a work based learning partnership.

\section{The organizational learning}

The organizational learning process helps people discover, why problems are seen in a one-dimensional framework, demanding questions of the current systems, and challenging and questioning paradoxes as they occur. Such a learning cycle exposes other problems for learners. Learners often never master their environments because they are gradually conditioned to act out imposed behaviours, lacking the opportunity to explore, discover, and experiment with environmental stimuli. There is a potential for firms to domesticate, oppress, and pacify those who learn. The rule by which behaviour is imposed through organizational language becomes a powerful driving force, and it is difficult for people to change the language once it has been imposed.

Human values and emotions play a significant role in effective organizational learning. Firms that have developed a strong learning culture are good at creating, acquiring and transferring knowledge and at modifying behaviour to reflect new knowledge and insight. Learning firms excel at creating shared vision, and allowing people to surface and challenge existing mental models. The competencies of a firm are what it can do as a result of resources working together whereas capabilities involve complex patterns of coordonation between people, and between people and other resources that lead to sustainable competitive advantage over time. Strategic actions are the manifestation of the competence that the learning has created and made possible.

Studies have found that some managerial competencies can be positively correlated to current business performance while others with effective organisational change. Superior technical and management competencies contribute to competitive advantage; management competencies have been found to create effective change in a variety of ways: commitment formation (achieving widespread commitment of the workforce), motivating and enthusing (motivating staff), enaction (taking timely and effective action), integration (coordinating action) and communication skills.

In addition to the organizational perspective, the performance appraisal literature has examined purpose from both the employee's and manager's differing and often conflicting perspectives, as well as from conflicting pressures within the manager. First, conflicting employee and manager goals make effective 
appraisals a difficult challenge. The employee is seeking to confirm his or her positive self-image, while the manager wishes to provide both negative and positive information to improve performance and promotability. Second, the manager has conflicting needs; the two main purpose of the review:

- counseling and development; and

- evaluation and discussion of administrative decisions, are in direct conflict.

In addition, forcing a manager into simultaneous roles of both counselor and judge can cause an employee to act defensively. Performance appraisals have many applications that arguably can become limitations to its different users.

We belive that a manager always plays the role of simultaneous evaluator and coach - and is always engaged in appraising - regardless if the topic at hand is an impromptu training session or a formal appraisal discussion, and whether or not the term "appraising" has been made explicit. We argue that if formal and informal performance appraisal discussions are framed using action inquiry dialogue, the quality of the conversation will increase. An action inquiry approach provides a forum for both the manager and employee to honestly address the manager's different roles (including those of evaluator and coach) and the employee's different responsibilities, with the intention of developmentaslly broadening both parties'awareness and creating a new shared purpose. As the value and mutuality of the dialogue increases, the quality of ongoing discussions between the manager and employee will improve and a focus on mutual learning and development will become primary.

An employee's satisfaction with the appraisal process is determined by a number of factors, including if the manager provides supervisory support, positively evaluating aspects of an employee's performance, offers guidance and establishes a climate of trust. The challenge is that managers and employees may have different perceptions of satisfaction with the appraisal process. Indeed, one study found that approximately half of the employees felt satisfied with their appraisal and its related discussion. In comparison, over 80 percent of their managers felt satisfied with the same event. Moreover, 53 percent of the managers reported that their employee's behavior improved after the appraisal, whereas only 41 percent of employees felt this was the case. Many managers were unaware of their employee's unmet needs. These results suggest that satisfaction with the appraisal process, whether it is managers' or employees' satisfaction, is not an adequate measure of effectiveness.

The organizational learning process helps people discover why problems are seen in a one-dimensional framework, demanding questions of the current systems, and challenging and questioning paradoxes as they occur. Such a learning cycle exposes other problems for learners. Learners often never master their environments because they are gradually conditioned to act out imposed behaviours, lacking the opportunity to explore, discover, and experiment with environmental stimuli. There is a potential for firms to domesticate, oppress, and pacify those who learn. The rule by which behaviour is imposed through organi- 
zational language becomes a powerful driving force, and it is difficult for people to change the language once it has been imposed.

An organisation's capacity to respond to the environment will be dependent on its coping capacity, perception and exploration process, and response capability. It follows that an organisation's schema or worldview (how it sees the world) will be highly advanced, or rather basic and inadequate in dealing with environmental stimuli. Evidence of superior learning through advanced belief systems underlies the creation of organisational competency. When groups work to create shared meaning from their experiences, whether good or bad, the collective experiences translate into an integrative ability, leading to greater capability that transcends individual experience. This process of integration combines both individual interpretation and group integration, and underpins a firm's organisation schema. The combination of interpreting and integration will result in a realised strategy that will represent one of four types of potential schema:

- impoverished,

- contentious,

- groupthink,

- productive schema.

When a firm's worldview consists of both high interpretive and high integrative schema, this is reflective of a dynamic set of complex views and shared understanding of environmental stimuli called productive schema.

Whereas a productive schema is the most favoured, an impoverished schema by comparison reflects low interpretation and integrative skills. In this mode, integrative schemas lack the complexity and diversity to interpret complex environments and there is little shared understanding. On the other hand, although groups may appear to be highly integrated by displaying shared group knowledge, they may lack the interpretive skills that rely on more advanced learning styles and complex thought patterns. Put simply, they display all the characteristics of a groupthink schema. The last of these is a contentious schema that consists of high interpretation but low integration skills. Possibly, a contentious schema is more evident when groups with different ideologies and values compete for attention and influence, and when management fails to construct a consensus for shared meaning and language that provides exlanations, rationalisations, and legitimation for the activities in the organisation.

Higher-level learning also involves the acquisition of skill or "know-how" the physical and operational ability to produce some action.

Higher-level learning requires an advanced organisational schema; advanced individual schemas together with the increased capacity of an organisation to create competencies, suggests that strategy will be more competitive and sustainable.

Higher-level learning also involves "know - why", the ability to articulate a conceptual understanding of an exerience.

Competencies can be used as a measure to determine levels of learning, and that any of four broad competencies (management competencies, operational 
competencies, technology competencies, learning competencies) will simultaneously show equal evidence of a group of learning routines, or different and superior routines.

\section{Conclusions}

Organisational learning appears to be useful when it is combined with competency development, and institutionalised in cultural routines.

The essence of the learning partnership has to be that it offers added value to both partners through the development of joint provision which is unique to that particular partnership and makes a genuine contribution to the intellectual capital of each of the partners.

To be effective as a learning organization there is a need for a deep learning cycle and recognition that it will take time. If organizational learning is seen as a continuous lerning cycle, then an organization can not arrive at a point in time when it declares itself ,a learning organization”, a noun or an end state. On the other hand, any organization can identify with being in a constant state of learning and declare itself to be practicing organizational learning. To sustain performance during times of constant change requires integrating performance and learning.

For the organisational learning, that integrates performance and learning results from the dynamic interaction between the sensemaking and structuring variables, play the human values and emotions a significant role.

\section{References}

Allison C.W., Hayes J., The cognitive style index:a measure of intuition - analysis for organisational research, „Journal of Management Studies”, 1996, Vol. 5, No. 3.

Argyris C., Education for leading-learning, „Organizational Dynamics”, 1993, Vol. 21, No. 3.

Argyris C., Good communication that blocks learning, „Harvard Business Review”, July-August 1994.

Buckley R.M., Ethical issues in human resource system, „Human Resource Management Review", 2001, Vol. 11.

Crossan M., Lane H.W., White R.E., An organizational learning framework: from intuition to institution, „Academy of Management Review”, 1999, Vol. 24 No. 3.

Dunphy D., Turner D., Crawford, Organisational learning as the creation of corporate competencies, Centre for Corporate Change, Australian Graduate School of Management, 1996.

Gorelick C., Organizational learning vs the learning organization: a conversation with a practitioner, „The Learning Organization”, 2005, Vol. 12, No. 4.

Holbrook R.L. Jr., Contact points and flash points:conceptualizing the use of justice mechanisms in the performance appraisal interview, „Human Resource Management Review”, 2002, Vol. 12.

Murray P., Donegan K., Empirical linkages between firm competencies and organisational learning, „The Learning Organization”, 2003, Vol. 10, No. 1. 
Schwandt D.R., Marquardt M.J., Organizational Learning: from World-class Theories to Global Best Practices, St. Lucie Press, Boca Raton 1999.

Suciu M.C., Economie. Noua economie si societatea bazata pe cunoastere, Ed.ASE, Bucuresti 2004.

Wilson J.P., Western S., Performance appraisal: an obstacle to training and development?, „Career Development International”, 2001, Vol. 6.

\section{Kapital intelektualny a organizacja ucząca się w spoleczeństwie opartym na wiedzy}

\section{Streszczenie}

Teoria organizacji uczqcej się okazuje się być praktyczna dla badaczy problemu, gdyż odnajduja $w$ niej zwiq̨zki między dwoma albo więcej zmiennymi, które moga być wykorzystane $w$ ocenie $i$ pomiarze wartości kapitału intelektualnego. Artykut podaje argumenty za wtaczeniem teorii organizacji uczqcej się do analizy zasobów kapitału intelektualnego i rozwoju społeczeństw opartych na wiedzy. 